\title{
Hubungan Antara Gegar Budaya Dengan Penyesuaian Sosial Siswa Papua di Magelang
}

\author{
Inosensia Dini Pramudiana \\ Fakultas Psikologi Universitas Katolik Soegijapranata \\ pramudianainosencia@gmail.com \\ Theresia Dewi Setyorini \\ Fakultas Psikologi Universitas Katolik Soegijapranata \\ thdewisrini@yahoo.co.id
}

\begin{abstract}
The efforts to improve the quality of education in Papua is done through education scholarship program, and one of them is by sending senior high school students in Papua to other regions for education. The movement of the students to other regions forces them to do social adjustments. In this situation, each individual often experiences shocks to the new cultures (culture shock). This research was conducted to empirically test the relationship of culture shock with social adjustment of Papuan students in Magelang. The hypothesis in this study is that there is a negative relationship between culture shock and the social adjustment of Papuan students who migrated to Magelang. The higher the culture shock is experienced, the lower the social adjustment ability is, and vice versa. The results of this study indicate that the proposed hypothesis is proved, that the culture shock is negatively correlated and very significant to social adjustment. The analysis between the culture shocks and social adjustments shows a strong relationship between the four aspects (stress reaction, cognitive fatigue, role shock, and personal shock) in culture shock with social adjustment. Among those four aspects, role shock aspect has the highest correlation coefficient. This shows that this aspect is the most closely related to the social adjustment of Papuan students in Magelang, and the least related is the stress reaction.
\end{abstract}

Keywords: culture shock, social adjustment, Papuan students

\begin{abstract}
Abstrak
Papua merupakan salah satu provinsi terkaya di Indonesia namun kualitas sumber daya di Papua masih rendah, tercatat Indeks Pembangunan Manusia di Papua tahun 2016 sebesar 57,25. Upaya untuk meningkatkan kulitas pendidikan di Papua dilakukan melalui program besiswa pendidikan, salah satunya dengan mengirim siswa SMA Papua keluar daerahnya untuk menempuh pendidikan. Pada masa ini siswa harus melakukan penyesuaian sosial. Penyesuaian sosial adalah kemampuan individu untuk berinteraksi secara sehat terhadap situasi sosial yang ada, sehingga mencapai kehidupan sosil yang menyenangkan. Dalam situasi ini, individu dapat mengalami kekagetan terhdap budaya yang baru (gegar budaya). Tujuan penelitian ini adalah untuk menguji secara empiric hubungan gegar budaya dengan penyesuaian sosial siswa Papua di Magelang. Hipotesis dari penelitian ini adalah ada hubungan negatif antara gegar budaya dengan penyesuaian sosial. Semakin tinggi gegar budaya, semakin rendah penyesuaian sosial, dan sebaliknya. Subyek dari penelitian ini adalah siswa Papua kelas XII dan XII di Magelang. Analisa data yang digunakan adalah uji korelasi Product Moment dengan menggunakan program SPSS (Statistical Packages for Social Sciences) seri 23.0. Analisa data menunjukan nilai $r=-0,548$ dan $p=0,000(p<0,005)$. Hal ini berarti hubungan yang terjadi antar dua variabel tidak searah. Semakin tinggi tingkat gegar budaya, semakin rendah tingkat penyesuaian sosial, dan sebaliknya.
\end{abstract}

Kata kunci: gegar budaya, penyesuaian sosial, siswa Papua 


\section{PENDAHULUAN}

Papua adalah daerah memiliki potensi sumber daya alam yang melimpah. Namun masyarakatnya tidak dapat sepenuhnya merasa dapat menikmatinya (bappenas.go.id). Hal ini terjadi karena kualitas sumber daya manusia di Papua yang masih rendah, dengan Indeks Pembangunan Manusia (IPM) tercatat sebesar 57,25 (BPS Provinsi Papua, 2016).

Pemerintah maupun yayasan swasta melakukan bergagai upaya untuk meningkatkan dan memeratakan pendidikan untuk masyarakat Papua, diantaranya melalui program Afirmasi Pendidikan Menengah (Adem) dan beasiswa pendidikan melalui Yayasan Binterbusih (Bina Teruni Bumi Cendrawasih). Melalui program beasiswa tersebut anak asli Papua berkesempatan untuk dapat melanjutkan pendidikan Sekolah Menengah Atas di Yogyakarta, Jawa (termasuk Magelang), Banten dan Bali.

Rata-rata siswa Sekolah Menengah Atas berusia antara 16 hingga 18 tahun, yang termasuk dalam masa remaja (Sarwono, 2016, h. 18). Pada masa ini, siswa harus melakukan penyesuaian dalam berbagai hal yang salah satunya adalah mengembangkan nilai-nilai yang sesuai dengan lingkungan dan kebudayaan serta memecahkan problem-problem nyata dalam pengalaman sendiri dan dalam kaitannya dengan lingkungan (Carballo dalam Sarwono, 2016, h. 19). Proses menyesuaikan diri individu dengan lingkungan di sekitarnya lebih dikenal dengan istilah penyesuaian sosial.

Penyesuaian sosial menurut Schneiders (dalam Susilowati, 2013) adalah kemampuan individu untuk berinteraksi secara sehat dan efektif terhadap hubungan serta kenyataan sosial yang ada, sehingga dapat mencapai kehidupan sosial yang menyenangkan. Chaplin (dalam Susilowati, 2013) mengartikan penyesuaian sosial sebagai suatu perjalinan secara harmonis suatu relasi dengan lingkungan sosial, serta mempelajari tingkah laku atau mengubah kebiasaan yang ada sedemikian rupa sehingga cocok bagi suatu masyarakat sosial.

Proses penyesuaian sosial tersebut dipengaruhi oleh beberapa faktor (Kartono dalam Agustin, 2007), diantaranya adalah kondisi fisik; konsep diri; kematangan taraf pertumbuhan dan perkembangan; determinan psikologis; kondisi lingkungan dan alam sekitar; serta adat istiadat, norma-norma sosial, kepercayaan dan kebudayaan. Faktor yang terakhir ini merupakan faktor yang mengatur perilaku individu dalam lingkungannya. Individu akan berusaha menyesuaikan diri dengan adat istiadat, norma, kepercayaan dan kebudayaan agar dapat diterima oleh lingkungan sosialnya. 
Namun hal tersebut tidaklah mudah bagi individu yang keluar dari lingkungan asalnya dan berada di lingkungan yang baru, sehingga individu tersebut harus kembali menyesuaikan dirinya dengan lingkungan baru tersebut. Dalam situasi seperti ini, individu dapat mengalami kekagetan terhadap budaya yang baru, atau yang biasa disebut dengan gegar budaya (culture shock).

Gegar budaya menurut Oberg (dalam Bochner, 2003). merupakan reaksi yang dimunculkan individu ketika berada dalam lingkungan yang asing untuknya. Furnham dan Bochner (dalam Devinta, dkk, 2015) berpendapat bahwa penyebab dari gegar budaya, yaitu kehilangan tanda-tanda yang biasa dikenali seperti ekspresi wajah maupun kebiasan-kebiasaan yang sering dilakukan, perbedaan bahasa, dan krisis identitas diri.

Dalam International Journal of Humanities and Social Science, terdapat penelitian mengenai Academic and Social Adjustment of Arab Fullbright Student in American Universities, dimana hasil dari penelitian tersebut menyatakan bahwa berpindahnya siswa Arab dari negara aslinya ke Amerika membuat mereka mengalami berbagai permasalahan yang disebabkan oleh adanya perbedaan bahasa, budaya, dan nilai yang mereka percaya, sehingga membuat mereka mengalami kesulitan dalam melakukan penyesuaian sosial (Al-Hattami \& Al-Ahdal, 2014). Perbedaan budaya yang terjadi, menurut Xia (2009)dapat menyebabkan terjadinya gegar budaya, dengan gejala yang ditimbulkan adalah perasaan tak biasa yang dapat berdampak menjadi stress psikologis, seperti depresi, timbulnya kecemasan dan perasaan tak berdaya.

Hasil penelitian lain yang dilakukan oleh Novianti, dkk di Yogyakarta pada mahasiswa Program Studi Ilmu Keperawatan, Fakultas Kedoktaran UGM yang berasal dari Banjarnegara (Jawa Tengah), Cirebon dan Serang (Jawa Barat), Batu Sangkar (Sumatera Barat), Sintang (Kalimantan Barat), dan Sumba Timur (Nusa Tenggara Timur) menunjukkan bahwa responden yang berasal dari daerah yang paling jauh memiliki peluang lebih besar untuk mengalami gegar budaya. Responden yang berasal dari Sumba Timur memiliki skor gegar budaya yang tertinggi dibandingkan dengan responden yang berasal dari Cirebon. Keadaan tersebut terjadi karena secara area budaya, Cirebon masih termasuk dalam kebudayaan Jawa, karena masyarakatnya masih menggunakan budaya Jawa dalam kehidupan sehari-hari (Novianti dkk, 2009).

Hasil survey dan wawancara menunjukan bahwa siswa Papua kurang mampu untuk memenuhi aspek-aspek penyesuaian sosial seperti yang diungkapkan 
oleh Runyon dan Haber (dalam Supriyadi dan Artha, 2013), mereka kurang mampu mengubah persepsi mereka sesuai dengan realitas kehidupan yang dijalani saat ini, mereka masih ingin budaya aslinya dijalankan di Magelang. Kemampuan mereka dalam menghadapi masalah yang terjadi dalam kehidupannya pun tidak berlangsung dengan baik, dua siswa Papua yang peneliti wawancara mengungkapkan bahwa banyak teman mereka yang terpaksa dipulangkan karena mengalami masalah selama di Magelang bahkan sampai jatuh sakit. Salah satu subyek yang peneliti wawancara sempat jatuh sakit dan sempat dipulangkan ke Papua untuk proses penyembuhan.

Selain itu, kemampuan mengelola emosi dari Siswa Papua di Magelang juga kurang baik, kedua subyek mengungkapkan bahwa ketika mereka kesal mereka akan mengeluarkan emosi dengan kemarahan dan teriakan. Bahkan salah satu subyek mengungkapkan bahwa dirinya pernah terlibat suatu kesalahpahaman dengan pengurus asrama, karena kesalahpahaman tersebut dia sempat "kabur" selama satu minggu dari asrama. Hubungan interpersonalnya dengan siswa Magelang pun tergolong kurang harmonis karena siswa Papua masih merasa kurang nyaman ketika menjalin pertemanan dengan siswa
Magelang karena perbedaan bahasa yang terjadi.

Berdasarkan pendalaman peneliti terhadap permasalahan yang terjadi, hal tersebut dapat terjadi karena para siswa Papua perantau ini merasa bingung terhadap perbedaan-perbedaan yang terjadi, sehingga siswa Papua sulit untuk memenuhi aspekaspek yang diperlukan dalam melakukan penyesuaian sosial terhadap lingkungan barunya.

Siswa Papua merantau ke Magelang mereka memiliki harapan untuk dapat mengenyam pendidikan dan lulus dengan hasil yang memuaskan di Magelang. Dalam proses pelaksanaannya, harapan siswa Papua tidak berjalan dengan baik, karena siswa Papua mengalami kesulitan dalam penyesusaian sosial di Magelang, akibat dari kekagetan budaya yang terjadi, sehingga banyak siswa yang tidak berhasil menempuh pendidikannya karena sakit dan harus dipulangkan ke Papua. Hal tersebut menimbulkan pertanyaan apakah ada pengaruh gegar budaya terhadap penyesuaian sosial, sehingga peneliti tertarik untuk membuat penelitian dengan judul "Hubungan Gegar Budaya dengan Penyesuaian Sosial Siswa Papua”. 


\section{LANDASAN TEORI}

\section{Penyesuaian Sosial}

Mappiere (dalam Ahyani dan Kumalasari, 2012) mengungkapkan bahwa penyesuaian diri merupakan usaha yang dilakukan individu sebagai usaha untuk dapat diterima oleh kelompok atau lingkungan sosialnya dengan mengikuti aturan yang ada di dalam kelompok tersebut. Ketika individu berinteraksi dengan lingkungan sosialnya, maka individu tersebut harus memahami dan memperhatikan tuntutan dan harapan sosial dari lingkungan terhadap perilakunya. Individu harus mencapai suatu kesepakatan antara kebutuhan atau keinginannya sendiri dengan tuntutan atau harapan dari lingkungan sosial, sehinga individu akan memeroleh kepuasan dalam dirinya (Yuwono dkk, 2006)

Yengimolki, dkk (2015) menegaskan bahwa penyesuaian sosial penting dalam kesehatan mental. Pertumbuhan sosial sangat penting dalam menentukan kemampuan penyesuaian sosial individu, dimana pertumbuhan sosial ini dapat diperoleh melalui bagaimana relasi individu dengan orang-orang terdekatnya. Dalam kehidupan sosial individu memiliki nilai atau pola-pola yang dianut dan untuk bertemu dengan individu lain dengan nilai maupun pola yang berbeda indivdu sangat perlu untuk melakukan penyesuaian, tanpa penyesuaian sosial individu tidak akan dapat berdamai dengan masyarakat, maka individu tersebut akan merasa terasing.

Runyon dan Haber (dalam Supriyadi dan Artha, 2013) juga membagi aspek penyesuaian sosial ke dalam lima bagian, diantaranya adalah:

a. Persepsi terhadap realitas Individu mampu untuk mengubah persepsinya sesuai dengan kenyataan hidupnya, sehingga individu tersebut mampu untuk menentukan tujuan hidup yang realistis.

b. Kemampuan mengatasi stress dan kecemasan

Individu mampu untuk menghadapi dan mengatasi masalah-masalah dalam hidupnya, mampu untuk menerima kegagalan yang terjadi dalam hidupnya.

c. Gambaran individu yang positif

Gambaran diri positif yang didapat individu melalui penilaian pribadi individu dan penilaian individu lain, sehingga individu akan merasakan kepuasan psikologis dan dapat menerima dirinya.

d. Kemampuan mengekspresikan emosi dengan baik

Individu mampu untuk mengolah dan mengontrol emosinya dengan baik, sehingga emosi tersebut dapat dikeluarkan individu dalam ekspresi yang positif.

e. Hubungan interpersonal yang baik Individu mampu untuk membentuk hubungan dengan cara yang berkualitas dan 
menghasilkan manfaat bagi dirinya dan individu lain.

Schneiders (dalam Muslihah, 2011), berpendapat bahwa penyesuaian sosial dipengaruhi oleh beberapa hal, diantaranya:

\section{a. Kondisi Fisik}

Apabila individu dapat menerima kondisi fisiknya dengan baik, akan membuat individu merasa percaya diri dan memudahkan individu tersebut dalam melakukan penyesuaian sosial dengan lingkungannya.

\section{b. Kematangan Perkembangan dan Pertumbuhan}

Kematangan intelektual, sosial, moral, dan emosional. Individu yang dapat memenuhi semua kematangan tersebut akan memiliki pola pikir yang lebih dewasa, sehingga individu dapat lebih baik dalam merespon lingkungannya dan melakukan penyesuaian di lingkungan sosial.

c. Penentu Psikologis

Pengalaman-pengalaman yang dimiliki individu, baik pengalaman traumatis, konflik maupun kebiasaan-kebiasaan yang sering individu lakukan di lingkungan lamanya akan mempengaruhi penyesuaian sosial individu ketika berada di lingkungan yang baru.

d. Kondisi Lingkungan

Kondisi lingkungan terdekat individu, seperti keadaan atau suasana rumah tinggal, keluarga, sekolah. Kondisi lingkungan yang mendukung akan mempermudah individu dalam melakukan penyesuaian sosial. e. Budaya

Faktor ini akan mengatur hubungan individu dan lingkunganya, dimana melalui faktor ini individu akan belajar untuk menyesuaiakan diri dengan adat istiadat, budaya maupun norma sosial yang berlaku di masyarakat.

Soeparwoto (dalam Ahyani dan Kumalasari, 2012) mengelompokkan faktor penyesuaian sosial menjadi dua bagian, yaitu:

a. Faktor internal

1. Motif

Motif yang dimaksud adalah motif sosial, seperti motif brafiliasi, motif berprestasi dan motif mendominasi.

\section{Konsep diri}

Individu dengan konsep diri yang tinggi akan lebih memiliki kemampuan untuk melakukan penyesuaian sosial yang menyenangkan dibandingkan dengan individu yang memiliki konsep diri rendah.

3. Persepsi

Pengamatan dan penilaian individu terhadap obyek, peristiwa dan kehidupan melalui proses kognisi maupun afeksi untuk membentuk konsep tentang obyek tertentu

4. Sikap

Kecenderungan individu untuk menentukan sikapnya, apakah individu akan berperilaku positif atau negatif. Individu yang bersikap 
positif terhadap segala sesuatu yang dihadapi akan lebih memiliki peluang yang lebih besar untuk dapat melakukan penyesuaian sosial yang baik daripada individu yang bersikap negatif.

5. Intelegensi dan minat Intelegensi merupakan modal yang dimiliki untuk mempu menganalisis segala sesuatu. Individu yang dapat menganalisis segala sesuatu dengan baik, dapat menjadi dasar dalam melakukan penyesuaian sosial dengan baik. Apabila intelegensi ditambah dengan minat maka akan lebih memberi pengaruh yang lebih besar terhadap kemampuan penyesuaian sosial individu. individu yang memiliki minat terhadap sesuatu, maka proses penyesuaian sosial lebih cepat.

6. Kepribadian

Individu yang memiliki kepribadian ekstrovert lebih lentur dan dinamis, sehingga lebih mudah dalam melakukan penyesuaian sosial dibanding dengan tipe kepribadian introvert yang cenderung memiliki sifat kaku dan statis.

b. Faktor eksternal

1. Keluarga terutama pola asuh orang tua

Pola asuh orang tua, terutama pola asuh demokratis dengan keterbukaan akan lebih memberi peluang bagi individu untuk melakukan penyesuaian sosial secara efektif.

2. Kondisi sekolah

Kondisi sekolah yang sehat akan menjadi landasan remaja untuk dapat melakukan penyesuaian sosial secara harmonis.

3. Kelompok sebaya

Teman sebaya yang saling mendukung akan menguntungkan individu dalam melakukan penyesuaian sosial, individu akan lebih mudah melakukan penyesuaian sosial dengan dukungan dari teman sebaya, begitu pula sebaliknya.

4. Prasangka social

Kecenderungan sebagian masyarakat untuk menaruh prasangka pada individu yang lainnya, dengan memberi label negatif, seperti nakal, sulit diatur, suka menentang orang tua akan menjadi kendala individu dalam melakukan penyesuaian sosial.

\section{Hukum dan norma social}

Hukum dan norma sosial atau budaya yang sudah menjadi kebiasaan di masyarakat akan membuat individu dapat mengembangkan diri dengan baik dan dapat melakukan penyesuaian sosial dengan baik.

Dari semua faktor tersebut, budaya memiliki pengaruh yang sangat penting dalam penyesuaian sosial, karena budaya sudah menjadi kebiasaan di masyarakat sehingga akan mengatur hubungan individu dan 
lingkungannya, sehingga individu dapat melakukan penyesuaian sosial dengan baik.

\section{GEGAR BUDAYA}

Oberg (dalam Bochner, 2003) menyatakan gegar budaya merupakan reaksi individu saat berada dalam lingkungan baru yang belum dikenalnya. Reaksi awal yang muncul adalah kecemasan akibat individu kehilangan tanda-tanda yang dikenalnya dalam lingkungan lamanya. Bochner (Furnharm dan Bochner, 2003) juga mengungkapkan bahwa reaksi yang muncul berupa perasaan tidak nyaman berada di lingkungan yang tidak dikenal, dimana apabila individu terus mengembangkan perasaan ini dan tidak melakukan penyesuaian terhadap lingkungan yang baru dapat menyebabkan individu mengalami stres.

Hammersley dan Atkinson (dalam Rianty \& Pujiriyani, 2010) mengungkapkan bahwa gegar budaya biasanya akan muncul pada hari-hari pertama individu datang ke lingkungan yang baru. Gegar budaya muncul karena ketika individu berada di lingkungan yang baru akan menemui kebiasaan-kebiasaan, adat maupun nilai-nilai yang berbeda dengan apa yang telah dianutnya di lingkungan yang lama, sehingga hal tersebut dapat menimbulkan trauma bagi dirinya.

Winkelmen (dalam Goldstein, 2015) mengemukakan empat aspek yang memnyebabkan gegar budaya, antara lain:

a. Stress Reaction

Stres menimbulkan reaksi fisiologis dalam jangkauan luas yang menyebabkan kerusakan fungsi sistem kekebalan tubuh dan meningkatkan kerentanan pada semua penyakit. Individu yang berada di lingkungan dan budaya yang baru mengalami pengalaman stres yang disebabkan oleh faktor fisiologis maupun psikologis. Keadaan psikologis memengaruhi tubuh dan reaksi fisiologisnya, yang meningkatkan rasa stress, cemas, depresi, gelisah. Gegar budaya mengakibatkan naiknya tingkat keprihatinan dengan penyakit, seolah-olah sakit secara fisik dengan berbagai gejala, penyakit minor dan ketidaknyamanan.

\section{b. Cognitive Fatigue}

Budaya yang baru menuntut suatu usaha yang penuh kesadaran untuk memahami halhal yang diproses tanpa disadari dalam budaya seseorang. Usaha harus dilakukan untuk memahami arti dari bahasa baru dan komunikasi nonverbal, dalam lingkungan sosial yang baru. Usaha yang penuh kesadaran dan menuntut perhatian untuk memahami semua informasi baru ini sangat melelahkan dan menghasilkan kepenatan mental dan emosional. Hal ini dapat menyebabkan sakit kepala yang tegang dan keinginan untuk 
mengasingkan diri dari kontak sosial terutama ketika timbunan kelebihan informasi meningkat.

\section{c. Role Shock}

Perubahan peran sosial dan relasi interpersonal memengaruhi kesejahteraan dan konsep diri, sehingga mengakibatkan individu mengalami syok peran. Dalam budaya yang baru, peran sebelumnya digantikan oleh peran yang belum dikenalnya. Hal tersebut menimbulkan syok peran yang dihasilkan dari ketidakjelasan posisi sosial dan hilangnya relasi dan peran sosial yang biasa dijalankan individu sebelumnya.

\section{d. Personal Shock}

Harga diri, identitas diri, kesejahteraan, kepuasan hidup dijaga oleh sistem budaya individu. Kehilangan sistem pendukung tersebut dapat menyebabkan kemerosotan rasa kesejahteraan individu dan menyebabkan munculnya gejala patologis. Gejala utama dari gegar budaya mencakup tidur yang berlebihan, makan dan minum yang bersifat kompulsif, menjadi cepat marah, rasa bermusuhan yang berlebihan, hilangnya efektifitas kerja dan menangis terus-terusan. Syok pribadi diperbesar dengan peristiwa dalam budaya baru yang menyalahi pengertian pribadi dan budaya individu mengenai moral dasar, nilai, logika dan kepercayaan tentang norma dan kesopanan. Konflik nilai berkontribusi untuk meningkatnya rasa konflik yang meluas dengan lingkungan.

\section{METODE PENELITIAN}

Populasi yang digunakan dalam penelitian ini adalah adalah Siswa Sekolah Menengah Atas, yang berada pada kelas X hingga XII yang berjumlah 106 siswa, berasal dari Papua dan bersekolah di Magelang. Sampel dalam penelitian adalah proportionatestratified random sampling dengan subyek siswa Papua kelas XI dan XII yang berjumlah 86 siswa sebagai sampel penelitian.

Peneliti melakukan pengumpulan data dengan menggunakan alat ukur berupa skala penyesuaian sosial dan skala gegar budaya. Skala tersebut berbentuk skala Likert.

\section{$\mathrm{H}_{1}$ : ada hubungan negatif antara gegar budaya dengan penyesuaian sosial siswa Papua yang merantau ke Magelang. Semakin tinggi gegar budaya yang dialami, semakin rendah kemampuan penyesuaian sosial, dan sebaliknya.}

\section{HASIL PENELITIAN DAN PEMBAHASAN}

Berdasarkan hasil uji hipotesis yang telah peneliti lakukan dengan menggunakan teknik korelasi pearson menunjukkan bahwa terdapat hubungan negatif antara gegar budaya dengan penyesuaian sosial dengan nilai $\mathrm{r}=-0,548$ dan $p=0,000 \quad(\mathrm{p}<0,005)$. Artinya, semakin tinggi tingkat gegar budaya, 
maka semakin rendah tingkat penyesuaian sosial, begitu pula sebaliknya. Korelasi sebesar 54,8\% tergolong korelasi yang kuat.

Penyesuaian sosial adalah usaha yang dilakukan individu agar dapat diterima oleh kelompok atau lingkungan sosialnya dengan mengikuti aturan yang ada dalam kelompok tersebut. Agar dapat diterima menjadi anggota kelompok, individu yang sedang dalam proses penyesuaian sosial lebih banyak mengabaikan kepentingan diri sendiri demi kepentingan kelompoknya (Mappiere dalam Ahyani dan Kumalasari, 2012). Penyesuaian sosial penting dalam kesehatan mental. Pertumbuhan sosial sangat penting dalam menentukan kemampuan penyesuaian sosial individu, dimana pertumbuhan sosial ini dapat diperoleh melalui bagaimana relasi individu dengan orang-orang terdekatnya (Yengimolki dkk, 2015). Runyon dan Haber (dalam Supriyadi dan Artha, 2013) membagi penyesuaian sosial ke dalam lima bagian, diantaranya persepsi tergadap realitas, kemampuan mengatasi stress dan kecemasan, gambaran individu yang positif, kemampuan mengekspresikan emosi dengan baik, hubungan interpersonal yang baik.

Gegar budaya merupakan reaksi individu saat berada dalam lingkungan baru yang belum dikenalnya. Reaksi awal yang muncul adalah kecemasan akibat individu kehilangan tanda-tanda yang dikenalnya dalam lingkungan lamanya (Oberg, dalam Bochner,2003). Gegar budaya muncul karena ketika individu berada di lingkungan yang baru akan menemui kebiasaan-kebiasaan, adat maupun nilai-nilai yang berbeda dengan apa yang telah dianutnya di lingkungan yang lama, sehingga hal tersebut dapat menimbulkan trauma bagi dirinya (Hammersley dan Atkinson dalam Rianty \& Pujiriyani, 2010).

Reaksi yang muncul berupa perasaan tidak nyaman berada di lingkungan yang tidak dikenal, dimana apabila individu terus mengembangkan perasaan ini dan tidak melakukan penyesuaian terhadap lingkungan yang baru dapat menyebabkan individu mengalami stress (Furnharm dan Bochner, 2003). Winkelmen (dalam Goldstein, 2015) terdapat empat aspek yang menyebabkan gegar budaya, antara lain Stress Reaction, Cognitive Fatigue, Role Shock dan Personal Shock. Keempat aspek tersebut berkaitan erat dengan kemampuan individu melakukan penyesuaian sosial, apabila semakin tinggi individu mengalami gegar budaya maka kemampuan individu melakakukan penyesuaian sosial akan rendah. Hasil penelitian ini menunjukan bahwa terdapat hubungan yang kuat yang terjadi antara keempat aspek dalam gegar budaya dengan 
penyesuaian sosial. Artinya, semakin tinggi tingkat stress reaction, cognitive fatigue, role shock, personal shock maka semakin rendah tingkat penyesuaian sosial.

Keempat aspek tersebut nilai koefisien korelasi yang paling tinggi adalah aspek role shock dengan nilai $\mathrm{r}=-0,501$ dan $p=0,000(\mathrm{p}<0,05)$. Hal ini menunjukan bahwa aspek ini paling erat kaitannya dengan penyesuaian sosial siswa Papua di Magelang, dimana perubahan peran sosial dan relasi interpersonal pada siswa Papua di Magelang sangat memengaruhi kesejahteraan dan konsep diri, sehingga menimbulkan syok peran dalam diri siswa Papua. Siswa Papua merasa kehilangan identitas yang selama ini dipertahankannya dalam proses perpindahan yang terjadi. Ketika siswa Papua berada di Magelang, berada jauh dari Papua, jauh dari orang tua dan relasi sosialnya, membuat peran yang selama ini dipertahankannya dalam lingkungan sosial asalnya harus digantikan dengan peran baru, menyesuaikan dengan budaya dan relasi sosialnya di Magelang. Ketidakjelasnan posisi sosial dan hilangnya peran sosial yang biasa dijalankan siswa di Papua tersebut membuat siswa mengalami syok peran, sehingga hal tersebut membuat siswa sulit untuk melakukan penyesuaian sosial. Aspek stress reaction menunjukan nilai koefisien korelasi yang paling rendah dengan nilai $\mathrm{r}=-0,336$ dan $p=0,023(\mathrm{p}<0,05)$. Hal ini menunjukan bahwa keadaan psikologis tidak terlalu memengaruhi kondisi tubuh dan reaksi fisiologis, yang meningkatkan rasa stress, cemas, depresi, gelisah pada siswa Papua.

\section{SIMPULAN}

Berdasarkan hasil penelitian yang dilakukan, maka terdapat kesimpulan sebagai berikut:

1. Hasil analisa menunjukan bahwa hipotesis yang mengarah hubungan negatif antara gegar budaya dengan penyesuaian sosial siswa Papua di Magelang diterima. Hal ini berarti bahwa semakin tinggi gegar budaya semakin rendah penyesuaian sosial, demikian pula sebaliknya diterima.

2. Hasil analisa data yang dilakukan pada penelitian hubungan gegar budaya dengan penyesuaian sosialmenunjukkan bahwa terdapat hubungan antara gegar budaya dengan penyesuaian sosial dengan nilai $r=$ 0,548 dan $(\mathrm{p}<0,005)$. Adapun korelasi sebesar 54,8\% tergolong korelasi yang kuat. Dari keempat aspek gegar budaya, yakni stress reaction, cognitive fatigue, role shock, personal shock. Nilai koefisien korelasi yang paling tinggi adalah aspek role shock dengan nilai $\mathrm{r}=-, 501$ dan $p=$ $0,000(\mathrm{p}<0,05)$. Artinya bahwa aspek ini paling erat kaitannya dengan penyesuaian sosial siswa Papua di Magelang. 


\section{Saran}

Berdasarkan penelitian yang telah dilakukan, maka peneliti dapat memberikan beberapa saran:

1. Bagi guru maupun pendamping asrama, sebaiknya:

a. Membantu siswa secara perlahan untuk mengenal budaya di lingkungan yang baru

b. Mencoba menemukan kesamaan nilai dalam budaya Jawa dan Papua agar siswa merasa lebih dekat dengan lingkungan tinggalnya yang baru, sehingga dapat mengurangi perasaan terasing akibat gegar budaya.

c. Bila memungkinkan sekolah dapat membuat suatu program, seperti “Live In”, dimana siswa Papua dapat berinteraksi secara langsung dan mengikuti keseharian warga asli Magelang, sehingga membuat siswa menjadi lebih dekat dengan masyarakat dan merasa dirinya diterima dilingkungan tinggalnya.।

2. Bagi subyek dalam penelitian ini, sebaiknya siswa lebih berusaha untuk membuka diri pada lingkungan juga relasi yang baru di lingkungan yang baru, sehingga siswa dapat lebih nyaman untuk tinggal di lingkungan yang baru dan dapat meminimalisir terjadinya gegar budaya.
3. Bagi peneliti selanjutnya yang ingin melakukan penelitian yang sama "Hubungan Gegar Budaya dengan Penyesuaian Sosial Siswa Papua”, disarankan untuk meningkatkan jumlah subyek penelitian agar dapat digeneralisasikan terhadap kelompok subyek dengan jumlah yang besar.

\section{DAFTAR PUSTAKA}

Ahyani, L.A., Kumalasari, F. (2012). Hubungan antara Dukungan Sosial dengan Penyesuaian Diri Remaja di Panti Asuhan. Jurnal Psikologi Pitutur, 1(1), 23-24

Agustin, L. (2007). Hubungan antara Konsep Diri dan Penyesuaian Mahasiswa Papua yang Kuliah di Yogyakarta. Skripsi : Tidak Diterbitkan, 21-22.

Al-Hattami, A. A., \& Al-Ahdal, A. A. (2014). Academic and Social Adjustment of Arab Fulbright Student in American Universities: A Case Study.International Journal of Humanities and Social Science. (4)/5 , 220.

Azwar, S. (2012). Reliabilitas dan Validitas. Yogyakarta: Pustaka Pelajar.

Bochner, S. (2003). Culture Shock Due to Contact with Unfamiliar Culture. Online Reading in Psychology and Culture , 1,4,7-9. 
BPS Provinsi Papua. (2016). Indeks Pembangunan Manusia (Ipm) Provinsi Papua 2015. Berita Resmi Statistik Provinsi Papua Nomor 32/06/94/Th.1.

Devinta, M., Hidayah, N., \& Hendrastomo. G. (2015). Fenomena Culture Shock (Gegar Budaya) pada Mahasiswa Perantau di Yogyakrta. Jurnal Pendidikan Sosiologi, 4.

Goldstein, S.B., Keller, S.R. (2015). U.S. College Students' Lay Theories of Culture Shock. International Journal of Intercultural Relations, (47)/189190.

Niam, E.K. (2009). Koping terhadap Stres pada Mahasiswa Luar Jawa yang Mengalami Culture Shock di Universitas Muahamadiyah Surakarta. Jurnal Ilmiah Berkala Psikologi. (11)/1, 72.

Novianti, D., Warsini, S., \& Suriyanto, R. A. (2009). Faktor-Faktor yang Mempengaruhi Culture Shock pada Mahasiswa Baru Angkatan 2008 PSIK FK UGM. JIK (04)/03, 174.
Muslihah, S. (2011). Studi tentang Hubungan Dukungan Sosial, Penyesuaian Sosial di Lingkungan Sekolah dan Prestasi Akademik Siswa SMPIT Assyfa Boarding School Subang Jawa Barat. Jurnal Psikologi Undip. 10/02, 108.

Paharizal, I. D. (2016). FREEPORT: Faktafakta yang Disembunyikan. Yogyakarta: Narasi, 11,17.

Ryanti A. \& Pujiriyani D.W. (2010). KiatKiat Mengantisipasi Culture Shock. Yogyakarta: PSAP UGM, 11.

Sarwono, S. W. (2016). Psikologi Remaja. Jakarta: PT Raja Grafindo Persada, 1819.

Seri Analisis Pembangunan Wilayah Profinsi Papua. Diambil 2 Agustus, 2017. http://simreg.bappenas.go.id

Sugiyono, (2014). Metode Penelitian kuantitatif Kualitatif dan R\&D. Bandung: Penerbit Alfabeta, 80,82,9293.

Supriyadi \& Artha I. N. M.W. (2013). Hubungan antara Kecerdasan Emosi dan Self Efficacy dalam Pemecahan Masalah Penyesuaian Diri Remaja Awal. Jurnal Psikologi Udayana. 1/1, 191. 
Susilowati, E. (2013). Kematangan Emosi dengan Penyesuaian Sosial Pada Siswa Akselerasi Tingkat SMP.Jurnal Online Psikologi, 105106.

Xia, J. (2009). Analysis of Impact of Culture Shock on Individual Psychology. International Journal of Psychological Studies. 1/ 2, 101.

Yuwono, S., Uyun Z., \& Setianingsih E. (2006). Hubungan antara Penyesuaian Sosial dan Kemampuan Menyelesaikan Masalah dengan Kecenderungan Perilaku Delinkuen pada Remaja. Jurnal Psikologi Universitas Diponegoro. 3/1, 31. 